\title{
ANALISIS PERKEMBANGAN INDEKS KESEJAHTERAAN MASYARAKAT KELAUTAN DAN PERIKANAN (IKMKP)
}

\section{Analysis of The Development Marine and Fisheries Welfare Community Index (IKMKP)}

\author{
*Yayan Hikmayani', Irwan Muliawan' dan Tukul Rameyo Adi ${ }^{2}$ \\ ${ }^{1}$ Balai Besar Riset Sosial Ekonomi Kelautan dan Perikanan \\ Gedung BRSDM KP I Lt. 4 \\ Jalan Pasir Putih Nomor 1 Ancol Timur, Jakarta Utara, Indonesia \\ Telp: (021) 64711583 Fax: 64700924 \\ ${ }^{2}$ Kementerian Koordinator Kemaritiman \\ Gedung BPPT 1 Lantai 3, Jalan M.H. Thamrin No. 8, Menteng, Kota Jakarta Pusat, Indonesia \\ Diterima tanggal: 8 April 2018 Diterima setelah perbaikan: 8 Nopember 2018 \\ Disetujui terbit: 26 Desember 2018 \\ email: yayanhikmayani@yahoo.ca
}

\begin{abstract}
ABSTRAK
Analisis terhadap perkembangan nilai Indeks Kesejahteraan Masyarakat Kelautan dan Perikanan (IKMKP) telah dilakukan sejak tahun 2014 sampai 2016. Permasalahan penentuan tingkat kesejahteraan dengan menyusun indikator yang mengarahkan pada pembangunan sektor kelautan dan perikanan secara sektoral dan menjadi wewenang Kementerian Kelautan dan Perikanan (KKP) adalah penting. Tujuan penulisan makalah ini untuk melihat kinerja pembangunan kelautan dan perikanan dilihat dari indikator kesejahteraan masyarakat pelaku usaha perikanan. Metode penelitian menggunakan metode desk study. Data terdiri data sekunder yang meliputi data ekonomi dan sosial kelembagaan yang dikumpulkan dan diperoleh dari Eselon 1 lingkup KKP. Verifikasi data dilakukan melalui diskusi kelompok terfokus yang dihadiri oleh pengambil kebijakan di Kementerian Kelautan dan Perikanan (KKP). Analisis data dilakukan menggunakan pendekatan deskriptif kuantitatif. Hasil penelitian menunjukkan bahwa nilai Indeks Kesejahteraan Masyarakat Kelautan dan Perikanan (IKMKP) tahun 2016 sebesar 48,33. Nilai dimensi sosial dan kelembagaan sebesar 43,31 dan nilai dimensi ekonomi sebesar 43,27. Daerah yang memiliki Nilai IKMKP terbesar yaitu Provinsi Nusa Tenggara Barat dengan nilai sebesar 100. Sementara itu, daerah yang memiliki nilai IKMKP paling kecil yaitu Provinsi Kalimantan Tengah dengan nilai sebesar 0,00 . Hasil tersebut mengindikasikan bahwa program-program pemerintah yang telah dialokasikan di Provinsi Nusa Tenggara Barat telah memberikan dampak positif terhadap peningkatan kesejahteraan dan sebaliknya untuk Provinsi Kalimantan Tengah masih belum memberikan dampak terhadap peningkatan kesejahteraaanya. Adapun dari analisa faktor penimbang, peningkatan kesejahteraan masyarakat kelautan dan perikanan akan lebih efektif jika semakin banyak jumlah Lembaga Ketahanan Masyarakat (LKM) yang terfasilitasi permodalan dan tidak terjadi perubahan komposisi pada struktur ongkos usaha perikanan.
\end{abstract}

Kata Kunci: indeks kesejahteraan masyarakat kelautan dan perikanan; pelaku utama kelautan dan perikanan

\section{ABSTRACT}

Analysis of the development of Marine and Fisheries Community Welfare Index (IKMKP) has been carried out since 2014 until 2016. It is important to determine the welfare level by formulating indicators to the development of the marine and fisheries sector through Ministry of Marine Affairs and Fisheries (MMAF). The purpose of this paper is to measure the performance of marine and fisheries development based on fisheries businessmen welfare indicators. The research used desk study method and secondary data of economic and social institutional which are collected from Echelon-1 of MMAF. Data were verified in focus group discussions among policy makers of MMAF and were analyzed using quantitative descriptive approach. The results showed that Marine and Fisheries Community Welfare Index (IKMKP) value in 2016 was 48.33. The value of social and institutional dimensions is 43.31 and value of economic dimension is 43.27. Regions that have the highest IKMKP value is West Nusa Tenggara Province with a value of 100. Meanwhile, Central Kalimantan Province has the lowest IKMKP 
value of 0.00 . These results indicate that government programs has contributed to the improvement of welfare in West Nusa Tenggara Province, meanwhile, it has not contributed to the welfare in Central Kalimantan Province. Based on weighted factor analysis, the welfare of marine and fisheries community will be more effective if there are more number of Community Resilience Institutions (MFIs) facilitated by capital and there is no changes in the structure of fisheries business costs.

Keywords: marine and fisheries community welfare index; marine and fisheries main actors

\section{PENDAHULUAN}

Kerangka 'Pembangunan Manusia' berisi beberapa gagasan yang sangat besar. Pemikiran utuh (Joined-up thinking) tidak dibatasi dalam kotak ekonomi nasional ataupun disiplin ilmu tertentu, namun menyangkut perasaan tergabung (Joined-up Feeling), simpati, perhatian, dan komitmen global (Gasper \& Truong, 2010). Seiring pendapat tersebut, program-program terkait dengan peningkatan pembangunan manusia melalui kesejahteraan masyarakat menjadi perhatian penting setiap pemerintahan baru. Isu tentang kesejahteraan memang selalu menjadi perhatian dan sebagai pertanda sukses tidaknya pembangunan yang dilakukan. Demikian juga dengan Kementerian kelautan dan Perikanan, isu kesejahteraan menjadi prioritas penting dalam menentukan capaian pembangunan kelautan dan perikanan dari tahun 2015-2019.

Rencana Strategis (Renstra) Kementerian Kelautan dan Perikanan tahun 2015-2019 menempakan kesejahteraan sebagai ukuran keberhasilan pembangunan. Dalam dokumen Renstra tersebut, di targetkan capaian indeks kesejahteraan masyarakat kelautan dan perikanan (IKMKP) pada tahun 2015 sebesar 40,5 dan sampai tahun 2019 sebesar 51 (KKP, 2015). Tentunya target yang sudah ditetapkan tersebut dijadikan sebagai pedoman untuk menyusun kebijakan, program dan kegiatan pembangunan kelautan dan perikanan. Untuk melihat capaian nilai IKMKP setiap tahun harus dilakukan pengukuran dan penghitungannya. Sebelumnya belum ada metode untuk mengukur dan menghitung IKMKP tersebut.

Berbagai indikator dapat digunakan untuk memantau kemajuan pembangunan di suatu daerah, baik indikator ekonomi maupun indikator sosial. Dalam konteks masyarakat sebagai obyek pembangunan, maka diperlukan suatu indikator untuk mengukur perkembangan kehidupan/tingkat kesejahteraan masyarakat itu sendiri. Untuk melihat gambaran tingkat kesejahteraan sosial dalam arti lebih sempit, dapat digunakan IMH (Indeks Mutu Hidup) karena indikator IMH hanya mempertimbangkan variabel-variabel sosial saja (United Nations Development Programme (UNDP), 2004).

Konsep pengukuran kesejahteraan masyarakat yang sudah diketahui yaitu Indeks Kesejahteraan Rakyat (IKraR) yang dikeluarkan oleh Kementerian Koordinator Kesejahteraan Rakyat (Kemenkokesra). Penghitungan dan analisis IKraR tersebut sudah dapat melihat kondisi tingkat kesejahteraan masyarakat Indonesia baik secara nasional maupun per lokasi provinsi dan kabupaten. Hasil analisis yang dilakukan dapat digunakan sebagai acuan porsi alokasi anggaran pembangunan dan perhatian lebih besar kepada wilayah-wilayah yang nilai IKraR nya masih rendah dan masukpadakategoritidaksejahtera. Masyarakat kelautan dan perikanan dengan karakteristik yang spesifik membutuhkan rumusan konsep yang bersifat spesifik untuk menghitung Kesejahteraan Masyarakat Kelautan dan Perikanan. Sementara itu, pengukuran kesejahteraan yang sifatnya spesifik tersebu sampai saat ini masih belum ada metodenya. Untuk itu, IKMKP dirumuskan dan mengacu pada konsep IKraR yang dapat digunakan mengukur kesejahteraan masyarakat kelautan dan perikanan.

Indeks Kesejahteraan Masyarakat Kelautan dan Perikanan (IKMKP) merupakan suatu gagasan baru untuk menghitung sejauh mana program-program KKP yang disampaikan kepada masyarakat berdampak pada peningkatan kesejahteraannya. Berbeda dengan indeks kesejahteraan lainnya, IKMKP merupakan model indeks yang mempertimbangkan kinerja programprogram yang berbasis pada pengembangan sumberdaya manusia, kelembagaan dan usaha-usaha sektor kelautan dan perikanan. Indeks ini pun dirancang lebih sektoral untuk kepentingan sektoral sehingga dapat digunakan untuk memberi gambaran kondisi kesejahteraan 
masyarakat kelautan dan perikanan. Indeks ini dapat memberi peluang secara terstruktur dan cukup jelas kepada pengambil kebijakan sektor $\mathrm{KP}$ untuk melakukan langkah-langkah guna meningkatkan kesejahteraan berdasarkan indikator sosial dan ekonomi.

Penulisan makalah ini bertujuan menyajikan hasil pengukuran dan penghitungan Indeks Kesejahteraan Masyarakat Kelautan dan Perikanan (IKMKP) pada tahun 2014 sampai 2016. Diharapkan dari hasil penghitungannya tersebut diperoleh gambaran secara nasional capaian dari target pembangunan. Disamping itu juga diperoleh gambaran keberhasilan program pembangunan yang dilakukan untuk setiap provinsi serta perkembangannya selama tiga tahun.

Penelitian dilakukan pada tahun 2014-2016 di DKI Jakarta dan Jawa Barat. Jenis data yang digunakan untuk menghitung IKMKP yaitu data sekunder. Data yang digunakan adalah data indikator pada dimensi ekonomi dan dimensi sosial kelembagaan. Masing-masing dimensi dibentuk dari 11 indikator. Kelembagaan pelaku utama merupakan salah satu indikator keberhasilan pembangunan KP. Peningkatan kelas kelembagaan pelaku utama merupakan dampak positif adanya program pembangunan. Dalam kasus perikanan tangkap, Wiyono dan Mustaruddin (2016) menyatakan bahwa faktor (variabel utama) yang mempengaruhi keberhasilan pembangunan perikanan tangkap adalah kelembagaan.

Dalam analisis ini penentuan indikator kelembagaan tersebut mengacu pada Keputusan Menteri Kelautan dan Perikanan Republik Indonesia Nomor Kep.14/Men/2012 tentang Pedoman Umum Penumbuhan dan Pengembangan Kelembagaan Pelaku Utama Perikanan. Indikator adalah sesuatu yang memberikan kunciuntuk pemahaman kompleks atau masalah yang lebih penting, bisa membuat jelas suatu kecenderungan atau fenomena yang tidak segera terdeteksi (De Wel, 1995), sedangkan dimensi adalah kumpulan indikator yang menjadi unit dalam pengelompokan indikator.

Data dimensi dan indikator pembentuk IKMKP serta sumber data dapat dilihat pada Tabel 1 dan 2.

Tabel 1. Indikator Penyusun Indeks Kesejahteraan Masyarakat Kelautan dan Perikanan untuk Dimensi Sosial dan Kelembagaan Tahun 2016.

Table 1. Indicator of Welfare Index for Marine and Fisheries People for Social and Institutional Dimension of 2016.

\begin{tabular}{|c|c|c|c|}
\hline & $\begin{array}{c}\text { Dimensi dan Atribut/ } \\
\text { Dimensions and Atributs }\end{array}$ & $\begin{array}{l}\text { Sumberl } \\
\text { Sources }\end{array}$ & $\begin{array}{l}\text { Skorl } \\
\text { Score }\end{array}$ \\
\hline $\mathrm{XS}_{1}$ & $\begin{array}{l}\text { Jumlah penumbuhan dan pengembangan } \\
\text { kelembagaan usaha perikanan tangkap } \\
\text { (KUB)/The number of growth and } \\
\text { development of capture fisheries business } \\
\text { institutions }\end{array}$ & $\begin{array}{l}\text { BRSDMKP/Agency of } \\
\text { Research and Human } \\
\text { Resources of Marine and } \\
\text { Fisheries }\end{array}$ & \multirow[t]{5}{*}{$\begin{array}{l}\text { 1. Jika proporsi perintis/if } \\
\text { proportion of pioneers }=75 \% \\
\text { 2. Jika proporsi perintis/ if } \\
\text { proportion of pioneers }=50-75 \% \\
\text { 3. Jika proporsi perintis/ if } \\
\text { Proportion of Pioneers }=<50 \%\end{array}$} \\
\hline$X S_{2}$ & $\begin{array}{l}\text { Jumlah penumbuhan dan pengembangan } \\
\text { kelembagaan usaha budidaya ikan } \\
\text { (Pokdakan)/The number of growth and } \\
\text { development of culture fisheries business } \\
\text { institutions }\end{array}$ & $\begin{array}{l}\text { BRSDMKPIAgency of } \\
\text { Research and Human } \\
\text { Resources of Marine and } \\
\text { Fisheries }\end{array}$ & \\
\hline $\mathrm{XS}_{3}$ & $\begin{array}{l}\text { Jumlah penumbuhan dan pengembangan } \\
\text { kelembagaan pemasaran perikanan } \\
\text { (Poklasar)/The number of growth and } \\
\text { development of fisheries marketing } \\
\text { institutions }\end{array}$ & $\begin{array}{l}\text { BRSDMKP/Agency of } \\
\text { Research and Human } \\
\text { Resources of Marine and } \\
\text { Fisheries }\end{array}$ & \\
\hline $\mathrm{XS}_{4}$ & $\begin{array}{l}\text { Jumlah penumbuhan dan pengembangan } \\
\text { kelembagaan usaha garam rakyat (Kugar)/ } \\
\text { Number of growth and development of } \\
\text { community salt bussiness }\end{array}$ & $\begin{array}{l}\text { BRSDMKP/Agency of } \\
\text { Research and Human } \\
\text { Resources of Marine and } \\
\text { Fisheries }\end{array}$ & \\
\hline $\mathrm{XS}_{5}$ & $\begin{array}{l}\text { Jumlah penumbuhan dan pengembangan } \\
\text { kelembagaan kelompok masyarakat } \\
\text { pengawas (Pokmaswas)/number of growth } \\
\text { and institutional development of community } \\
\text { surveilance group }\end{array}$ & $\begin{array}{l}\text { BRSDMKP/Agency of } \\
\text { Research And Human } \\
\text { Resources of Marine and } \\
\text { Fisheries }\end{array}$ & \\
\hline
\end{tabular}




\section{Lanjutan Tabel 1/Continues Table 1}

\begin{tabular}{|c|c|c|c|}
\hline & $\begin{array}{c}\text { Dimensi dan Atribut/ } \\
\text { Dimensions and Atributs }\end{array}$ & $\begin{array}{l}\text { Sumberl } \\
\text { Sources }\end{array}$ & $\begin{array}{l}\text { Skorl } \\
\text { Score }\end{array}$ \\
\hline $\mathrm{XS}_{6}$ & $\begin{array}{l}\text { Jumlah kelembagaan usaha yang terpantau } \\
\text { dan terevaluasi/yang mendapatkan bantuan } \\
\text { fasilitas/Number of business institutions that } \\
\text { are monitored and evaluated/who received } \\
\text { facility assistance }\end{array}$ & $\begin{array}{l}\text { DJ-PT/Directorate } \\
\text { General of Capture } \\
\text { Fisheries, } \\
\text { DJ-PB/Directorate } \\
\text { General of Culture } \\
\text { Fisheries, } \\
\text { DJ-PDSPKP/Directorate } \\
\text { General of Product } \\
\text { Improvement and } \\
\text { Competitiveness }\end{array}$ & $\begin{array}{l}\text { 1. Tidak termanfaatkan/Not } \\
\text { Utilized } \\
\text { 2. Termanfaatkan sebagian/ } \\
\text { Partially Utilized } \\
\text { 3. termanfaatkan keseluruhan/ } \\
\text { Utilized entirely }\end{array}$ \\
\hline $\mathrm{XS}_{7}$ & $\begin{array}{l}\text { Jumlah masyarakat adat, tradisional } \\
\text { dan lokal yang direvitalisasi/The number } \\
\text { of indigenous, traditional and local } \\
\text { communities being revitalized }\end{array}$ & $\begin{array}{l}\text { DJ-PRL/Directorate } \\
\text { General of Marine Spatial } \\
\text { Management }\end{array}$ & $\begin{array}{l}\text { 1. Tidak terevitalisasi/Not } \\
\text { revitalized } \\
\text { 2. Terevitalisasi sebagian/Partially } \\
\text { revitalized } \\
\text { 3. Terevitalisasi seluruhnya/ } \\
\text { Revitalized entirely }\end{array}$ \\
\hline $\mathrm{XS}_{8}$ & $\begin{array}{l}\text { Jumlah LKM pesisir yang terfasilitasi } \\
\text { permodalannya di kawasan pesisir dan } \\
\text { pulau kecil/Number of coastal microfinance } \\
\text { institutions facilitated by capital in coastal } \\
\text { areas and small islands/ }\end{array}$ & $\begin{array}{l}\text { DJ-PRL/ Directorate } \\
\text { General of Marine Spatial } \\
\text { Management }\end{array}$ & $\begin{array}{l}\text { 1. Tidak terfasilitasi/Not facilitated } \\
\text { 2. Terfasilitasi sebagian/Partially } \\
\text { facilitated } \\
\text { 3. Terfasilitasi seluruhnya/ } \\
\text { Facilitated entirely }\end{array}$ \\
\hline $\mathrm{XS}_{9}$ & $\begin{array}{l}\text { Jumlah pelaku usaha mikro yang mandiri } \\
\text { di kawasan pesisir dan pulau-pulau kecil/ } \\
\text { Number of independent micro business } \\
\text { actors in coastal areas and small islands }\end{array}$ & $\begin{array}{l}\text { DJ-PRL/Directorate } \\
\text { General of Marine Spatial } \\
\text { Management }\end{array}$ & $\begin{array}{l}\text { 1. Tidak ada yang mandiri/Not } \\
\text { Independent } \\
\text { 2. Mandiri sebagian/Partially } \\
\text { independent } \\
\text { 3. Mandiri seluruhnya/Independent } \\
\text { entirely }\end{array}$ \\
\hline $\mathrm{XS}_{10}$ & $\begin{array}{l}\text { Jumlah kelompok pelaku utama/usaha yang } \\
\text { meningkat kelasnya dari jumlah kelompok } \\
\text { pelaku utama/usaha yang disuluh/ The } \\
\text { number of embedded principal/business } \\
\text { actors and improved in class }\end{array}$ & $\begin{array}{l}\text { BRSDMKP/ Agency of } \\
\text { Research and Human } \\
\text { Resources of Marine and } \\
\text { Fisheries }\end{array}$ & $\begin{array}{l}\text { 1. Tidak ada peningkatan kelas/ } \\
\text { Fail to upgrade } \\
\text { 2. Ada peningkatan kelas } \\
\text { sebagian/Upgrade partially } \\
\text { 3. Peningkatan kelas seluruhnya/ } \\
\text { Upgrade entirely }\end{array}$ \\
\hline $\mathrm{XS}_{11}$ & $\begin{array}{l}\text { Jumlah kelompok yang disuluh mendukung } \\
\text { tata kelola pemanfaatan sumber daya KP } \\
\text { yang berdaya saing dan berkelanjutan/The } \\
\text { number of embedded groups supports the } \\
\text { governance of competent and sustainable } \\
\text { KP resource utilization }\end{array}$ & $\begin{array}{l}\text { BRSDMKP/Agency of } \\
\text { Research and Human } \\
\text { Resources of Marine and } \\
\text { Fisheries }\end{array}$ & $\begin{array}{l}\text { 1. Disuluh tidak mendukung/ } \\
\text { Embedded and not supportive } \\
\text { 2. Disuluh dan sebagian } \\
\text { mendukung/Embedded and } \\
\text { partially supportive } \\
\text { 3. Disuluh dan mendukung/ } \\
\text { Embedded and supportive }\end{array}$ \\
\hline
\end{tabular}

Sumber: Balai Besar Riset Sosial Ekonomi Kelautan Perikanan (2015)/

Source: Research Center for Marine and Fisheries Socio Economic (2015) 
Tabel 2. Indikator Penyusun Indeks Kesejahteraan Masyarakat Kelautan dan Perikanan untuk Dimensi Ekonomi Tahun 2016.

Table 2. Indicator of Welfare Index for Marine and Fisheries People for Economic Dimension 2016.

\begin{tabular}{|c|c|c|c|}
\hline & $\begin{array}{l}\text { Dimensi dan Atribut/ } \\
\text { Dimensions and Atributs }\end{array}$ & Sumber/Sources & Skor/Score \\
\hline $\mathrm{XE}_{1}$ & $\begin{array}{l}\text { Nilai Tukar Nelayan (NTN)/ Fisher's } \\
\text { terms of trade (FTT) }\end{array}$ & $\begin{array}{l}\text { DJ-PT/Directorate General of } \\
\text { Capture Fisheries, }\end{array}$ & $\begin{array}{ll}\text { 1. } & \text { NTN } / F T T<100 \\
\text { 2. } & \text { NTN } / F T T=100 \\
\text { 3. } & \text { NTN } / F T T>100\end{array}$ \\
\hline$X E_{2}$ & $\begin{array}{l}\text { Nilai Tukar Pembudidaya (NTPi)/ } \\
\text { Fish farmer's terms of trade (FFTT) }\end{array}$ & $\begin{array}{l}\text { DJ-PB/Directorate General of } \\
\text { Culture Fisheries, }\end{array}$ & $\begin{array}{ll}\text { 1. } & \mathrm{NTPi} / F F T T<100 \\
\text { 2. } & \mathrm{NTPi} / F F T T=100 \\
\text { 3. } & \mathrm{NTPi} / F F T T>100\end{array}$ \\
\hline$X E_{3}$ & $\begin{array}{l}\text { Nilai Tukar Pengolah (NTPo)/ Fish } \\
\text { product processor's terms of trade } \\
\text { (FPTT) }\end{array}$ & $\begin{array}{l}\text { DJ-PDSPKPIDirectorate } \\
\text { General of Product } \\
\text { Improvement and } \\
\text { Competitiveness }\end{array}$ & $\begin{array}{ll}\text { 1. } & \text { NTPo/FPTT }<100 \\
\text { 2. } & \text { NTPo/FPTT }=100 \\
\text { 3. } & \text { NTPo/FPTT }>100\end{array}$ \\
\hline $\mathrm{XE}_{4}$ & $\begin{array}{l}\text { Nilai Tukar Petambak Garam } \\
\text { (NTPG)/ Salt farmer's terms of } \\
\text { trade (SFTT) }\end{array}$ & $\begin{array}{l}\text { DJ-PRL/Directorate } \\
\text { General of Marine Spatial } \\
\text { Management }\end{array}$ & $\begin{array}{l}\text { 1. } \mathrm{NTPg} / S F T T<100 \\
\text { 2. } \mathrm{NTPg} / S F T T=100 \\
\text { 3. } \mathrm{NTPg} / S F T T>100\end{array}$ \\
\hline $\mathrm{XE}_{5}$ & $\begin{array}{l}\text { Rata-rata pendapatan nelayan per } \\
\text { bulanbulan/Average fisher's income } \\
\text { per months }\end{array}$ & $\begin{array}{l}\text { DJ-PT/Directorate General of } \\
\text { Capture }\end{array}$ & $\begin{array}{l}\text { 1. Di bawah UMR per bulan/Under } \\
\text { the Regional Minimum Wage per } \\
\text { month } \\
\text { 2. Sama dengan UMR per bulan/ } \\
\text { Equal to the RegionalMinimum } \\
\text { Wage per month } \\
\text { 3. Diatas UMR per bulan/Above } \\
\text { the Regional Minimum Wage per } \\
\text { month }\end{array}$ \\
\hline$X E_{6}$ & $\begin{array}{l}\text { Rata-rata pendapatan } \\
\text { pembudidaya per bulan/Average } \\
\text { fish farmers income per months }\end{array}$ & $\begin{array}{l}\text { DJ-PB/Directorate General of } \\
\text { Culture Fisheries, }\end{array}$ & $\begin{array}{l}\text { 1. Di bawah UMR per bulan/Under } \\
\text { the Regional Minimum Wage per } \\
\text { month } \\
\text { 2. Sama dengan UMR per bulan/ } \\
\text { Equal to the Regional Minimum } \\
\text { Wage per month } \\
\text { 3. Di atas UMR per bulan/Above } \\
\text { the Regional Minimum Wage per } \\
\text { month }\end{array}$ \\
\hline$X E_{7}$ & $\begin{array}{l}\text { Rata-rata pendapatan pengolah } \\
\text { perikanan per bulan/Average fish } \\
\text { product processor income per } \\
\text { months }\end{array}$ & $\begin{array}{l}\text { DJ-PDSPKP/ Directorate } \\
\text { General of Product } \\
\text { Improvement and } \\
\text { Competitiveness }\end{array}$ & $\begin{array}{l}\text { 1. Di bawah UMR per bulan/ Under } \\
\text { the Regional Minimum Wage per } \\
\text { month } \\
\text { 2. Sama dengan UMR per bulan/ } \\
\text { Equal to the RegionalMinimum } \\
\text { Wage per month } \\
\text { 3. Di atas UMR per bulan/ Above } \\
\text { the Regional Minimum Wage per } \\
\text { month }\end{array}$ \\
\hline $\mathrm{XE}_{8}$ & $\begin{array}{l}\text { Rata-rata pendapatan petambak } \\
\text { garam/bulan/ Average salt farmers } \\
\text { income per months }\end{array}$ & $\begin{array}{l}\text { DJ-PRL/ Directorate } \\
\text { General of Marine Spatial } \\
\text { Management }\end{array}$ & $\begin{array}{l}\text { 1. Dibawah UMR per bulan/Under } \\
\text { the Regional Minimum Wage per } \\
\text { month } \\
\text { 2. Sama dengan UMR per bulan/ } \\
\text { Equal to the Regional Minimum } \\
\text { Wage per month } \\
\text { 3. Diatas UMR per bulan/Above } \\
\text { the Regional Minimum Wage per } \\
\text { month }\end{array}$ \\
\hline $\mathrm{XE}_{9}$ & $\begin{array}{l}\text { Jumlah kawasan wisata bahari } \\
\text { yang dikembangkan/ Number of } \\
\text { marine tourism areas developed }\end{array}$ & $\begin{array}{l}\text { DJ-PRL/ Directorate } \\
\text { General of Marine Spatial } \\
\text { Management }\end{array}$ & $\begin{array}{l}\text { 1. Terjadi penurunan jumlah kawasan/ } \\
\text { Decrease in the number of areas } \\
\text { 2. Jumlah kawasan tetap/The number } \\
\text { of areas has not changed } \\
\text { 3. Terjadi peningkatan jumlah } \\
\text { kawasan/Increase in the number of } \\
\text { areas }\end{array}$ \\
\hline
\end{tabular}


Lanjutan Tabel 2/Continues Table 2

\begin{tabular}{|c|c|c|c|}
\hline & $\begin{array}{l}\text { Dimensi dan Atribut/ } \\
\text { Dimensions and Atributs }\end{array}$ & Sumber/Sources & Skor/Score \\
\hline $\mathrm{XE}_{10}$ & $\begin{array}{l}\text { Proporsi pengeluaran pangan } \\
\text { terhadap total pendapatan/ The } \\
\text { proportion of food expenditure on } \\
\text { total income }\end{array}$ & $\begin{array}{l}\text { BPS/Central Bureau of } \\
\text { Statistics }\end{array}$ & $\begin{array}{l}\text { 1. Proporsi pengeluaran pangan } \\
\text { diatas } 60 \% \text { dari total pendapatan/ } \\
\text { Proportion of food expenditure } \\
\text { above } 60 \% \text { of total income } \\
\text { 2. Proporsi pengeluaran pangan } \\
\text { sama dengan non pangan/The } \\
\text { proportion of food expenditure is } \\
\text { the same as non-food } \\
\text { 3. Proporsi pengeluaran pangan } \\
\text { lebih kecil dari non pangan/The } \\
\text { proportion of food expenditure is } \\
\text { smaller than non-food }\end{array}$ \\
\hline$X E_{11}$ & $\begin{array}{l}\text { Struktur ongkos usaha perikanan/ } \\
\text { Cost structure of fishery }\end{array}$ & $\begin{array}{l}\text { BRSDMKP/Agency of } \\
\text { Research and Human } \\
\text { Resources of Marine and } \\
\text { Fisheries }\end{array}$ & $\begin{array}{l}\text { 1. Jika terjadi komposisi terbesar } \\
\text { pada biaya tertentu/lf there is } \\
\text { greatest composition at a certain } \\
\text { cost } \\
\text { 2. Jika tidak terjadi perubahan } \\
\text { komposisi/lf there is no change of } \\
\text { composition } \\
\text { 3. Jika terjadi komposisi yang } \\
\text { berimbang pada biaya tertentu/lf } \\
\text { there is a balanced composition at } \\
\text { a certain cost }\end{array}$ \\
\hline
\end{tabular}

Sumber: Balai Besar Riset Sosial Ekonomi Kelautan Perikanan (2015)/

Source: Research Center for Marine and Fisheries Socio Economic (2015)

Metode pengambilan data dilakukan melalui wawancara langsung dengan bagian statistik setiap direktorat teknis lingkup KKP yaitu Direkorat Jenderal Perikanan Tangkap, Direkorat Jenderal Perikanan Budidaya, Direktorat Jenderal Peningkatan Daya Saing, Direktorat Jenderal Pengelolaan Ruang Laut, Badan Riset dan SDM, dan Direkorat Jenderal Pengawasan Sumberdaya Kelautan Dan Perikanan. Selain wawancara pengambilan dan verifikasi data dilakukan melalui Focus Group Discussion (FGD). Adapun tahapan metode analisis yang digunakan adalah, sebagai berikut:

\section{1) Perapihan Data}

Data yang berhasil dikumpulkan sebagian besar belum dalam bentuk sesuai dengan yang didefinisikan untuk keperluan penyusunan kategori di masing-masing indikator. Oleh karena itu dilakukan perapihan dan penyesuaian. Perapihan data dalam proses penyusunan IKMKP ini dilakukan untuk dimensi sosial dan kelembagan dan dimensi ekonomi.

\section{2) Penyusunan Model}

Penyusunan model untuk IKMKP berdasarkan kesepakatan hasil Focus Group Discusion terdiri dari $60 \%$ faktor sosial dan $40 \%$ faktor ekonomi. Faktor social dianggap lebih dominan disbanding factor ekonomi. Penghitungan IKMKP masingmasing provinsi dihitung dengan rumus sebagai berikut:

$$
I K M K P i=0,6 I X S o s i+0,4 I X E k o i
$$

Subskrip i menunjukkan provinsi ke i, IXS merupakan indeks komposit dimensi sosial dan kelembagaan dan IXE adalah indeks komposit dimensi ekonomi. Data diinput dalam Microsoft excel untuk selanjutnya dilakukan pengolahan data dengan menggunakan Software Stata 12 untuk mendapatkan bobot penimbang ( $w$ dan $w$ ). Dengan melihat ketersediaan data indikator yang ada maka indeks yang akan diperoleh untuk dimensi sosial dan kelembagaan (IXS) adalah rumus berikut:

Penjumlahan skor dimensi Sosial dan Kelembangaan:

$$
I X S_{i}=w_{1} X S 1_{i}+w_{2} X S 2_{i}+\cdots \cdots+w_{11} X S 11_{i}
$$

Normalisasi skor dimensi dimensi Sosial dan Kelembangaan:

IXSosi $=($ IXSi- IXS min $) /(I X S m a x-I X S \min ) \times 100$

Selanjutnya indeks yang akan diperoleh untuk dimensi ekonomi (IXE) adalah rumus berikut: 
Penjumlahan skor dimensi Ekonomi:

$$
I X E i=\omega_{1} X E 1_{i}+\omega_{2} X E 2_{i}+\cdots \cdots+\omega_{11} X E 11_{i}
$$

Normalisasi skor dimensi dimensi Sosial dan Kelembangaan:

IXEkoi $=(I X E i-I X E \min ) /($ IXE max- IXE min $) \times 100$

Dalam rumus tersebut $\mathrm{w}$ dan $\omega$ merupakan penimbang yang diperoleh analisiskomponen utama (principal component analysis). Penimbang w dan $\omega$ masing-masing adalah koefisien dari koefisien principal component pertama yang diasumsikan dapat mewakili kondisi sosial dan kelembagaan dan kondisi ekonomi.

Skor untuk masing-masing indikator merupakan hasil kompilasi dari kelompok data perkembangan dari tiap indikator itu sendiri. Skor telah ditetapkan terbagi menjadi tiga nilai skor, sebagaimana telah diuraikan pada tabel 1 dan tabel 2. Kategorisasi skor pada dilakukan menyesuaikan perkembangan indikator tersebut di tiap kabupaten.

\section{Penentuan Penimbang Indeks}

Penentuan penimbang indeks indikator menggunakan metode statistik Analisis FaktorUtama/Principal Component Analysis (PCA). PCA dilakukan dalam setiap dimensi IKMKP yaitu dimensi sosial dan kelembagaan, dan dimensi ekonomi. Penimbang yang diperoleh merupakan bobot setiap indeks indikator dalam menyusun dimensinya. Penimbang $w$ dan $\omega$ adalah nilai bobot berdasarkan nilai dari indikator baik indikator dari dimensi ekonomi maupun indikator dari dimensi sosial kelembagaan. Secara teknis metoda penentuan bobot yang digunakan dalam PCA adalah teknik Eigen (Eigen Method) sebagaimana banyak dilakukan penentuan bobot prioritas(Saaty, 1993).

\section{Penghitungan IKMKP}

Penghitungan IKMKP menggunakan analisis faktor terhadap seluruh indikator yang masuk ke dalam dimensi sosial dan kelembagaan, dan dimensi ekonomi. Secara teoritis analisis faktor termasuk dalam analisis multivariate yang secara umum dimaksudkan untuk mencari hubungan antar variabel dari berbagai variabel yang dimasukkan baik independen maupun dependen. Analisis faktor adalah teknik yang digunakan untuk mengidentifikasi faktor-faktor yang jumlahnya relatif kecil yang dapat digunakan untuk menunjukkan hubungan-hubungan antar variabel-variabel yang mempunyai kaitan satu sama lain, Norusis (1993). Kekuatan-kekuatan hubungan tersebut dinyatakan dengan intrepretasi dari interval nilai yang ditetapkan yang biasanya dinyatakan dalam kategori lemah, moderat, kuat dan amat kuat. Angka hasil penghitungan tersebut kemudian dikategorisasikan ke dalam tingkat kategori tingkat kesejahteraan tertentu, yang dilegendakan dengan warna yang berbeda. Warna merah merupakan IKMKP terendah dan warna hijau tua menunjukan IKMKP tertinggi (Gambar 2).

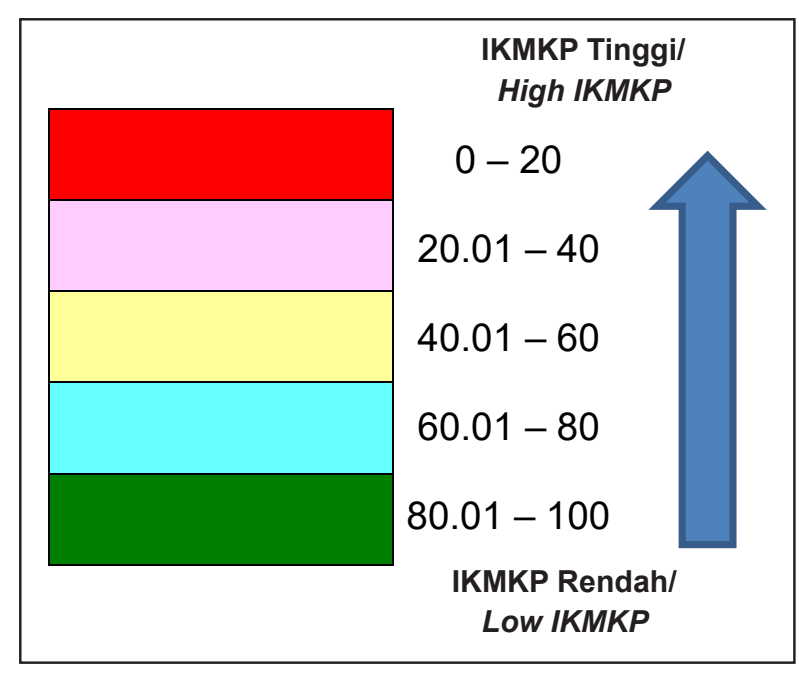

Gambar 2. Legenda IKMKP.

Figure 2. IKMKP Legend.

Sumber: Kemenkokesra, diolah, 2012

Source: Ministry of People's Welfare Coordinator, 2012, modified)

\section{PENGHITUNGAN INDEKS KESEJAHTERAAN MASYARAKAT KELAUTAN DAN PERIKANAN (IKMKP) TAHUN 2016}

Penghitungan IKMKP dilakukan terhadap seluruh dimensi, baik dimensi sosial kelembagaan dan dimensi ekonomi. Hasil analisis PCA untuk dimensi sosial dan kelembagaan disajikan pada Tabel 3. Berdasarkan output Stata, koefisien dari PCA yang terpilih untuk indikator-indikator dalam dimensi sosial dan kelembagaan dapat dilihat pada Tabel 3.

Dengan demikian rumus untuk penghitungan indeks dimensi sosial dan kelembagaan adalah:

$$
\begin{aligned}
I X S_{i}= & 0,4420 X S 1_{i}+0,4025 X S 2_{i}+0,4177 X S 3_{i} \\
& +0,3417 X S 4_{i}+0,4751 X S 5_{i}+0,3181 X S 6_{i} \\
& +0,5122 X S 7_{i}+0,0229 X S 8_{i}+0,5009 X S 9_{i} \\
& +0,5009 X S 9_{i}+0,2647 X S 10_{i}+0,3800 X S 11_{i}
\end{aligned}
$$


Tabel 3. Koefisien Output Analisis Stata untuk Dimensi Sosial dan Kelembagaan Penghitungan IKMKP 2016.

Table 3. Output Coefficient Stata Analysis for Social Dimension and Institutional Calculation of IKMKP 2016.

\begin{tabular}{ccc}
\hline No. & Indikator/ Indicator & Nilai Koefisien/ Coefficient Value \\
\hline 1 & $\mathrm{XS}_{1}$ & 0.4420 \\
2 & $\mathrm{XS}_{2}$ & 0.4025 \\
3 & $\mathrm{XS}_{3}$ & 0.4177 \\
4 & $\mathrm{XS}_{4}$ & 0.3417 \\
5 & $\mathrm{XS}_{5}$ & 0.4751 \\
6 & $\mathrm{XS}_{6}$ & 0.3181 \\
7 & $\mathrm{XS}_{7}$ & 0.5122 \\
8 & $\mathrm{XS}_{8}$ & 0.0229 \\
9 & $\mathrm{XS}_{9}$ & 0.5009 \\
10 & $\mathrm{XS}_{10}$ & 0.2647 \\
11 & $\mathrm{XS}_{11}$ & 0.3800 \\
\hline
\end{tabular}

Sumber: Hasil Analisis Data (2017)/ Source: Data Analyzed Result (2017)

Berdasarkan output Stata, koefisien dari PCA yang terpilih untuk indikator-indikator dalam dimensi ekonomi dapat dilihat pada Tabel 4.
Selanjutnya diperoleh hasil penghitungan IKMKP menurut provinsi sesuai hasil analisis PCA disajikan pada Tabel 5.

Tabel 4. Koefisien Output Analisis Stata untuk Dimensi Ekonomi Penghitungan IKMKP 2016. Table 4. Output Coefficient Stata Analysis for Economic Dimension Calculation of IKMKP, 2016.

\begin{tabular}{ccc}
\hline No & Indikator/ Indicator & Nilai koefisien/ Coefficient Value \\
\hline 1 & $\mathrm{XE}_{1}$ & 0.3912 \\
2 & $\mathrm{XE}_{2}$ & 0.1887 \\
3 & $\mathrm{XE}_{3}$ & 0.3970 \\
4 & $\mathrm{XE}_{4}$ & 0.5285 \\
5 & $\mathrm{XE}_{5}$ & 0.5001 \\
6 & $\mathrm{XE}_{6}$ & 0.3369 \\
7 & $\mathrm{XE}_{7}$ & 0.3869 \\
8 & $\mathrm{XE}_{8}$ & 0.4870 \\
9 & $\mathrm{XE}_{9}$ & 0.5845 \\
10 & $\mathrm{XE}_{10}$ & 0.1957 \\
11 & $\mathrm{XE}_{11}$ & 0.1034 \\
\hline
\end{tabular}

Dengan demikian rumus untuk penghitungan indeks dimensi ekonomi adalah:

$$
\begin{aligned}
I X E_{i}= & 0,3912 X E 1_{i}+0,1887 X E 2_{i}+0,3970 X E 3_{i} \\
& +0,5285 X E 4_{i}+0,5001 X E 5_{i}+0,3369 X E 6_{i} \\
& +0,3869 X E 7_{i}+0,4870 X E 8_{i}+0,5845 X E 9_{i} \\
& +0,1957 X E 10_{i}+0,1957 X E 10_{i}+0,1034 X E 11_{i}
\end{aligned}
$$

Dengan demikian rumus untuk penghitungan indeks dimensi sosial dankelembagaan adalah:

$$
\begin{aligned}
I X S_{i}= & 0,4420 X S 1_{i}+0,4025 X S 2_{i}+0,4177 X S 3_{i} \\
& +0,3417 X S 4_{i}+0,4751 X S 5_{i}+0,3181 X S 6_{i} \\
& +0,5122 X S 7_{i}+0,0229 X S 8_{i}+0,5009 X S 9_{i}- \\
& +0,2647 X S 10_{i}+0,2647 X S 10_{i}+0,3800 X S 11_{i}
\end{aligned}
$$

Hasil penghitungan Indeks Kesejahteraan Masyarakat Kelautan Perikanan (IKMKP) tahun 2016 secara nasional menunjukkan angka sebesar 48,33. Dengan nilai tersebut menunjukkan bahwa pelaku utama usaha kelautan dan perikanan berada pada kondisi relatif sejahtera karena berada pada selang antara 40.01-60. Nilai IKMKP yang dicapai pada tahun 2016 yaitu sebesar 48,33 tersebut masih lebih tinggi dibanding target nilai indeks kesejahteraan yang sudah ditentukan untuk tahun 2016 yang tercantum dalam Rencana Strategis (RENSTRA) KKP sebesar 42.

Nilai capaian masing-masing dimensi dengan nilai IKMKP sebesar 48,33 terdiri dari 
Tabel 5. Hasil Penghitungan IKMKP menurut Provinsi Tahun 2015.

Table 5. Result of Calculation of IKMKP by Province of 2015.

\begin{tabular}{|c|c|c|c|c|c|}
\hline \multirow[t]{2}{*}{ No } & \multirow[t]{2}{*}{ Provinsi } & \multicolumn{3}{|c|}{ Normalisasi } & \multirow[t]{2}{*}{$\begin{array}{l}\text { Ranking } \\
\text { IKMKP }\end{array}$} \\
\hline & & IXS & IXE & IKMKP & \\
\hline 1 & Aceh & 33.12 & 100,00 & 71,94 & 8 \\
\hline 2 & Sumatera Utara & - & 33,05 & 3,94 & 33 \\
\hline 3 & Sumatera Barat & 49.92 & 53,41 & 60,04 & 13 \\
\hline 4 & Riau & 44.04 & 24,35 & 38,08 & 23 \\
\hline 5 & Jambi & 35.50 & - & 16,46 & 30 \\
\hline 6 & Sumatera Selatan & 33.57 & 43,43 & 39,76 & 20 \\
\hline 7 & Bengkulu & 21.67 & 25,39 & 18,79 & 28 \\
\hline 8 & Lampung & 17.12 & 43,43 & 25,13 & 26 \\
\hline 9 & Kepulauan Bangka Belitung & 28.54 & 48,77 & 38,36 & 22 \\
\hline 10 & Kepulauan Riau & 30.17 & 51,94 & 41,64 & 19 \\
\hline 11 & Dki Jakarta & 53.33 & 38,43 & 54,44 & 14 \\
\hline 12 & Jawa Barat & 55.42 & 96,43 & 89,71 & 4 \\
\hline 13 & Jawa Tengah & 4.02 & 96,43 & 44,02 & 17 \\
\hline 14 & D I Yogyakarta & 44.16 & 25,50 & 38,84 & 21 \\
\hline 15 & Jawa Timur & 28.50 & 99,40 & 67,49 & 10 \\
\hline 16 & Banten & 25.07 & 38,28 & 29,24 & 25 \\
\hline 17 & Bali & 77.94 & 20,55 & 66,02 & 11 \\
\hline 18 & Nusa Tenggara Barat & 75.94 & 82,63 & 100,00 & 1 \\
\hline 19 & Nusa Tenggara Timur & 75.62 & 52,18 & 82,18 & 6 \\
\hline 20 & Kalimantan Barat & 84.39 & 17,48 & 69,98 & 9 \\
\hline 21 & Kalimantan Tengah & 14.62 & 3,65 & - & 34 \\
\hline 22 & Kalimantan Selatan & 42.04 & 36,27 & 43,16 & 18 \\
\hline 23 & Kalimantan Timur & 26.61 & 6,56 & 12,33 & 31 \\
\hline 24 & Kalimantan Utara & 11.78 & 20,75 & 7,33 & 32 \\
\hline 25 & Sulawesi Utara & 22.94 & 67,75 & 44,32 & 16 \\
\hline 26 & Sulawesi Tengah & 51.55 & 29,59 & 47,77 & 15 \\
\hline 27 & Sulawesi Selatan & 58.34 & 77,90 & 81,63 & 7 \\
\hline 28 & Sulawesi Tenggara & 91.90 & 50,19 & 95,50 & 3 \\
\hline 29 & Gorontalo & 100.00 & 24,07 & 87,65 & 5 \\
\hline 30 & Sulawesi Barat & 79.45 & 13,83 & 63,49 & 12 \\
\hline 31 & Maluku & 93.20 & 48,52 & 95,69 & 2 \\
\hline 32 & Maluku Utara & 10.93 & 38,19 & 16,62 & 29 \\
\hline 33 & Papua & 26.13 & 24,32 & 22,14 & 27 \\
\hline 34 & Papua Barat & 25.13 & 38,43 & 29,38 & 24 \\
\hline \multicolumn{2}{|r|}{ Indonesia } & 43,31 & 43.27 & 48,33 & \\
\hline
\end{tabular}

Keterangan: IXS=Indeks Sosial dan Kelembagaan; IXE=Indeks Ekonomi/

Remaks: IXS = Social and Institutional Index; IXE= Economic Index

dimensi sosial dan kelembagaan sebesar 43,31 dan capaian dimensi ekonomi sebesar 43,27. Nilai tersebut menunjukkan bahwa dari kedua dimensi memberikan sumbangan yang hampir sama antara dimensi sosial kelembagaan dan dimensi ekonomi. Nilai IKMKP yang diperoleh tersebut juga mengindikasikan bahwa programprogram pembangunan yang dilakukan oleh KKP kepada pelaku utama usaha kelautan dan perikanan telah memberikan manfaat terhadap peningkatan kesejahteraannya. kemiskinan adalah indikator keberhasilan pembangunan. Nilai sosial kelembagaan sebesar 43,31 tersebut sejalan dengan pernyataan Wiyono dan Mustaruddin (2016) bahwa faktor (variabel utama) yang mempengaruhi keberhasilan pembangunan perikanan tangkap adalah kelembagaan.

Hasil penghitungan Indeks Kesejahteraan Masyarakat Kelautan Perikanan (IKMKP) tahun 
2016 secara nasional menunjukkan angka sebesar 48,33. Nilai tersebut menunjukkan bahwa pelaku utama usaha kelautan dan perikanan berada pada kondisi relatif sejahtera karena berada pada selang antara 40.01- 60. Dari nilai tersebut juga diketahui bahwa program-program bantuan pemerintah untuk masyarakat telah memberikan dampak adanya peningkatan kesejahteraan. Nilai IKMKP yang dicapai pada tahun 2016 yaitu sebesar 48,33 tersebut masih lebih tinggi dibanding target nilai indeks kesejahteraan yang sudah ditentukan untuk tahun 2016 yang tercantum dalam Rencana Strategis (RENSTRA) KKP sebesar 42.

Nilai capaian masing-masing dimensi dengan nilai IKMKP sebesar 48,33 terdiri dari dimensi sosial dan kelembagaan sebesar 43,31 dan capaian dimensi ekonomi sebesar 43,27. Nilai tersebut menunjukkan bahwa dari kedua dimensi memberikan sumbangan yang hampir sama antara dimensi sosial kelembagaan dan dimensi ekonomi. Nilai IKMKP yang diperoleh tersebut juga mengindikasikan bahwa programprogram pembangunan yang dilakukan oleh KKP kepada pelaku utama usaha kelautan dan perikanan telah memberikan manfaat terhadap peningkatan kesejahteraannya. Nilai dimensi sosial kelembagaan sebesar 43,31 menunjukkan bahwa indikator-indikator dari dimensi social kelembagaan memberikan peran cukup besar terhadap peningkatan kesejahteraan pelaku usaha tertama yang mendapatkan program KKP. Hasil tersebut sejalan dengan pernyataan Wiyono dan Mustaruddin (2016) yang menyatakan bahwa faktor (variabel utama) yang mempengaruhi keberhasilan pembangunan perikanan tangkap adalah kelembagaan.

\section{PERKEMBANGAN INDEKS KESEJAHTERAAN MASYARAKAT KELAUTAN DAN PERIKANAN TAHUN 2014-2016}

Penghitungan IKMKP tahun 2014-2016 dilakukan dengan tujuan untuk melihat perkembangan IKMKP selama tiga tahun terakhir apakah menurun atau meningkat dan apa yang menyebabkannya. Dari hasil penghitungan IKMKP 2014-2016 menunjukkan bahwa nilai IKMKP meningkat selama tiga tahun berturut-turut yaitu 40,52 tahun 2014, 48,15 tahun 2015 dan 48,33 tahun 2016 (Tabel 6). Dengan demikian, dapat dikatakan bahwa program-program KKP yang dilakukan berdampak pada peningkatan kesejahteraan pelaku usaha kelautan dan perikanan yang dilakukan selama tiga tahun terakhir.

Tabel 6. Nilai IKMKP Tiap Provinsi Tahun 2014 - 2016.

Table 6. IKMKP Value for Each Province 2014 - 2016.

\begin{tabular}{|c|c|c|c|c|}
\hline \multirow{2}{*}{ No } & \multirow{2}{*}{ Provinsi } & \multicolumn{3}{|c|}{ Tahun } \\
\hline & & 2014 & 2015 & 2016 \\
\hline 1 & Aceh & 64,1 & 100,00 & 71,94 \\
\hline 2 & Sumatera Utara & 25,8 & 18,53 & 3,94 \\
\hline 3 & Sumatera Barat & 36,6 & 39,23 & 60,04 \\
\hline 4 & Riau & 58,6 & 55,26 & 38,08 \\
\hline 5 & Jambi & 60,8 & 46,84 & 16,46 \\
\hline 6 & Sumatera Selatan & 49,0 & 29,35 & 39,76 \\
\hline 7 & Bengkulu & 29,2 & 18,62 & 18,79 \\
\hline 8 & Lampung & 80,7 & 50,79 & 25,13 \\
\hline 9 & Kepulauan Bangka Belitung & 25,3 & 24,61 & 38,36 \\
\hline 10 & Kepulauan Riau & 55,8 & 62,91 & 41,64 \\
\hline 11 & DKI Jakarta & 34,3 & 25,08 & 54,44 \\
\hline 12 & Jawa Barat & 84,0 & 68,87 & 89,71 \\
\hline 13 & Jawa Tengah & 33,0 & 48,81 & 44,02 \\
\hline 14 & D I Yogyakarta & 100,0 & 79,45 & 38,84 \\
\hline 15 & Jawa Timur & 91,1 & 86,49 & 67,49 \\
\hline 16 & Banten & 66,3 & 54,49 & 29,24 \\
\hline 17 & Bali & 82,7 & 78,16 & 66,02 \\
\hline 18 & Nusa Tenggara Barat & 48,8 & 84,15 & 100,00 \\
\hline 19 & Nusa Tenggara Timur & 73,8 & 94,65 & 82,18 \\
\hline 20 & Kalimantan Barat & 44,4 & 59,70 & 69,98 \\
\hline 21 & Kalimantan Tengah & 15,1 & 0,00 & 0,00 \\
\hline 22 & Kalimantan Selatan & 73,2 & 47,14 & 43,16 \\
\hline
\end{tabular}




\section{Lanjutan Tabel 6/Continues Table 6}

\begin{tabular}{|c|c|c|c|c|}
\hline \multirow{2}{*}{ No } & \multirow{2}{*}{ Provinsi } & \multicolumn{3}{|c|}{ Tahun } \\
\hline & & 2014 & 2015 & 2016 \\
\hline 23 & Kalimantan Timur & 0,0 & 20,27 & 12,33 \\
\hline 24 & Kalimantan Utara & 12,2 & 8,20 & 7,33 \\
\hline 25 & Sulawesi Utara & 6,7 & 32,48 & 44,32 \\
\hline 26 & Sulawesi Tengah & 47,7 & 38,64 & 47,77 \\
\hline 27 & Sulawesi Selatan & 82,1 & 76,81 & 81,63 \\
\hline 28 & Sulawesi Tenggara & 67,4 & 48,30 & 95,50 \\
\hline 29 & Gorontalo & 30,7 & 56,88 & 87,65 \\
\hline 30 & Sulawesi Barat & 52,4 & 49,38 & 63,49 \\
\hline 31 & Maluku & 80,2 & 72,14 & 95,69 \\
\hline 32 & Maluku Utara & 41,0 & 12,20 & 16,62 \\
\hline 33 & Papua Barat & 18,0 & 35,85 & 22,14 \\
\hline 34 & Papua & 25,3 & 12,72 & 29,38 \\
\hline & Jumlah/Total & 40,52 & 48,15 & 48,33 \\
\hline
\end{tabular}

Apabila dilihat berdasarkan sebaran masing-masing provinsi, nilai IKMKP terendah selama tahun 2015-2016 yaitu terjadi di Provinsi Kalimantan Tengah. Sementara itu, daerah yang memiliki perbaikan kesejahteraan dapat dilihat dari perubahan nilai IKMKP sejak tahun 2014-2016 (Tabel 10). Empat provinsi yang memiliki nilai indeks kesejahteraan yang meningkat dengan kisaran nilai 80 - 100\% yaitu Nusa Tenggara Barat, Sulawesi Tenggara, Gorontalo, dan Jawa Barat. Sementara 5 (lima) provinsi yang indeks kesejahteraanya menurun dengan kisaran nilai $<20 \%$ yaitu Provinsi Sumatera Utara, Jambi, Kalimantan Tengah, Kalimantan Timur, dan Kalimantan Utara.

Peningkatan nilai IKMKP tidak diikuti oleh peningkatan baik pada nilai dimensi sosial kelembagaan maupun dimensi ekonominya. Perkembangan nilai IKMKP menurut masingmasing dimensinya selama tahun 2014-2016 dapat dilihat pada Gambar 3. Pada gambar tersebut menunjukkan bahwa perkembangan nilai IKMKP tidak diikuti oleh peningkatan nilai untuk kedua dimensinya. Kedua dimensi menujukkan bahwa terjadi peningkatan nilai dari tahun 2014 ke tahun 2015, namun kemudian nilainya menurun pada tahun 2016. Terjadinya penurunan nilai-nilai pada kedua dimensi pada tahun 2016 tersebut di duga sebagai dampak dari berbagai kebijakan KKP yang dikeluarkan pada tahun 2016 yang sedang memprioritaskan pemberantasan Illegal Fishing, sehingga terdapat pelaku usaha yang terdampak langsung dengan kebijakan tersebut.

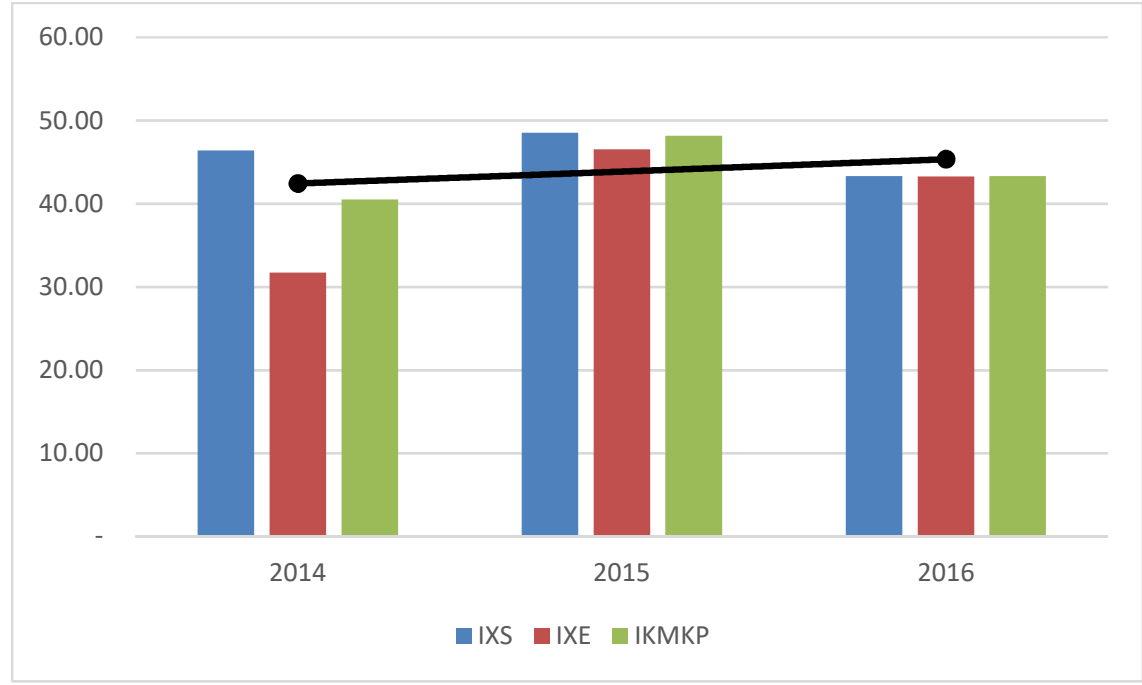

Gambar 3. IKMKP Tahun $2014-2016$.

Figure 3. IKMKP 2014 - 2016. 


\section{ANALISIS MENURUT SEBARAN PROVINSI}

Nilai-nilai IKMKP selanjutnya dituangkan dalam informasi yang berbentuk peta, tabel dan grafik yang sudah menjadi satu kesatuan informasinya. Warna-warna legenda yang disebutkan pada Gambar 2 selanjutnya disajikan ke dalam warna peta yang berbeda-beda untuk setiap wilayah peta baik provinsi maupun kabupaten atau kota. Pewarnaan yang diambil dalam mengkategori kondisi indeks kesejahteraan rakyat adalah berbeda-beda dimana warna untuk kelompok indeks kesejahteraan rakyat terendah adalah berwarna merah tua dan warna untuk kelompok indeks kesejahteraan rakyat tertinggi adalah hijau tua.

Dari ketiga gambar tersebut menunjukkan bahwa telah terjadi pergeseran IKMKP terutama untuk provinsi yang awalnya ditandai dengan warna merah kemudian berubah menjadi kuning dan hijau. Namun, sebaliknya juga terdapat wilayah yang awalnya ditandai dengan warna hijau atau kuning berubah menjadi merah. Untuk melihat kesenjangan antar wilayah dapat dilihat dengan cara membandingkan beberapa wilayah di Indonesia dari nilai IKMKP nya. Dari data hasil perhitungan diketahui bahwa nilai IKMKP terbesar di miliki oleh Provinsi Nusa Tenggara
Barat dengan nilai IKMKP sebesar 100 ditandai dengan warna hijau. Hal ini menunjukkan bahwa masyarakat pelaku usaha KP di provinsi tersebut berada pada kondisi sangat sejahtera. Hal ini didukung dari Laporan Kinerja Instansi Pemerintah provinsi NTB yang menunjukkan bahwa NTN yang tinggi pada indeks 108,07 atau naik 102,92\% sementara nilai tukar pembudidaya ikan pada indeks 89,71 atau tercapai $101,94 \%$ dari target tahun 2016 (Dinas Kelautan dan Perikanan Provinsi NTB, 2017).

Sebaliknya, peringkat ke-34 yaitu Provinsi Kalimantan Tengah dengan nilai IKMKP sebesar 0,00 dapat dikatakan tidak sejahtera dan ditandai dengan warna merah. Kondisi demikian, sejalan dengan permasalahan yang dihadapi pada sektor perikanan yaitu dengan masih rendahnya produktivitas dan daya saing usaha kelautan dan perikanan yang disebabkan oleh struktur armada penangkapan ikan yang masih didominasi oleh kapal berukuran kecil, belum optimalnya integrasi sistem produksi di hulu dan hilir, serta masih terbatasnya penyediaan sarana dan prasarana secara memadai. Di samping itu, aspek sangat mendasar yang mempengaruhi lemahnya daya saing dan produktivitas adalah kualitas SDM dan kelembagaannya (Dinas KP Prov. Kalimantan Tengah 2017)
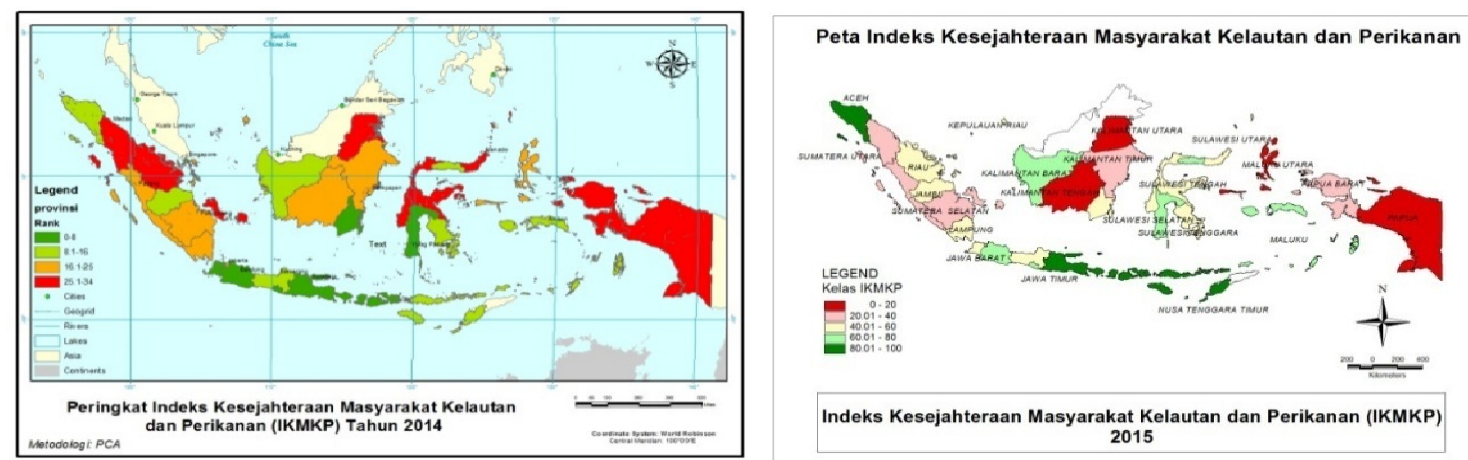

Peta Indeks Kesejahteraan Masyarakat Kelautan dan Perikanan

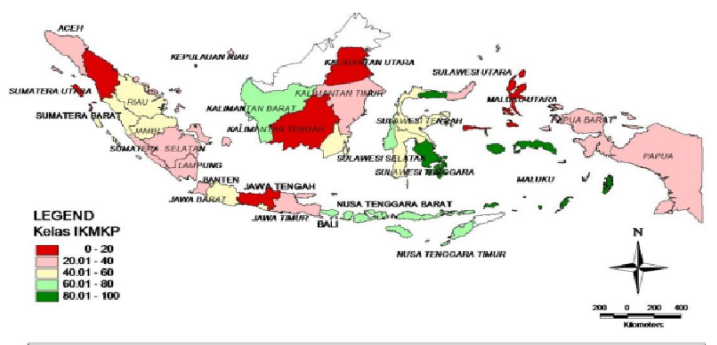

Indeks Kesejahteraan Masyarakat Kelautan dan Perikanan (IKMKP) 2016

Gambar 5. Peta IKMKP 2014-2016.

Figure 5. Map of IKMKP Map 2014 - 2015. 
Dimensi sosial dan kelembagaan mencerminkan keadilan sosial dan kelembagaan tidak hanya menyangkut persoalan proses distribusi atau pemerataan hasil-hasil pembangunan kelautan dan perikanan, tapi berkaitan juga dengan upaya pemenuhan kebutuhan dasar, serta tindakan afirmatif dari KKP untuk melindungi dan memastikan setiap nelayan tradisional, pembudidaya, pengolah, pemasar, dan petambak mendapatkan kemudahan akses terhadap pemenuhan terhadap hak dasarnya, seperti pangan, papan, sandang, pelayanan publik, infrastruktur, serta pemberdayaan masyarakat sehingga mengurangi kesenjangan sosial ekonomi.

Dimensi ekonomi dalam konteks kesejahteraan masyarakat dilihat dari indikatorindikator yang terkait kemampuan para nelayan tradisional, pembudidaya, petambak, pengolah, dan pemasar untuk mendapatkan kemudahan akses dan aset terhadap sumber daya ekonomi untuk mencapai kesejahteraannya. Sedangkan untuk nilai IKMKP pada dimensi ekonomi yang yaitu Jambi, Kalimantan Barat, Kalimantan Tengah, Kalimantan Timurdan SulawesiBarat. Sebagaimana diutarakan Riyanto (2003), desentralisasi fiskal dapat mendorong pertumbuhan dan pemerataan ekonomi daerah sehingga kesejahteraan masyarakat meningkat dan lebih merata. Sebagai contoh provinsi Kalimantan tengah dirangsang untuk meningkat peningkatan ekonomi mikro serta mengembangkan wisata bahari disana. Hal ini karena kedua indikator tersebut memiliki bobot yang tinggi untuk meningkatkan kesejahteraan masyarakat.

Indikator ini berguna untuk menunjukkan gambaran umum kesejahteraan hasil pelaksanan kebijakan, program dan strategi yang selama ini telah dilakukan. Manfaat nyata terhadap pembangunan manusia adalah perhatian plural menyangkut segala aspek dan membawa pada evaluasi yang terus menerus mengikuti perkembangannya terjadi (Sen, 2000)

\section{PENUTUP}

Trend Capaian IKMKP pada Tahun 2014-2016 meningkat dan dapat dikatakan bahwa program pembangunan yang dilakukan sekor KP telah cukup memberikan dampak bagi kesejahteraan pelaku usahanya. Peningkatan nilai IKMKP selama periode 2014 - 2016 tidak diikuti oleh peningkatan nilai untuk masing-masing dimensinya. Wilayah yang memiliki perkembangan nilai IKMKP yang membaik selama tahun 2014-2016 yaitu Nusa Tenggara Barat, Gorontalo dan Jawa Barat. Sementara wilayah dengan perkembangan yang menurun yaitu Sumatera Utara, Jambi, Banten, Kalimantan Tengah, Kalimantan Selatan dan Maluku Utara.

Hasil penghitungan IKMKP dapat dijadikan sebagai bahan untuk pengambilan kebijakan khususnya KKP. Dari hasil penghitungan tersebut beberapa hal perlu ditindaklanjuti yaitu prioritas pembangunan untuk daerah-daerah yang memiliki nilai IKMKP nya masih rendah bahkan ada yang nilainya 0,00 dan ditandai dengan warna merah serta kuning. Penghitungan IKMKP ke depan sebaiknya juga dilakukan untuk tingkat kabupaten supaya lebih mudah menentukan daerah prioritas untuk pelaksanaan pembangunan. Dalam upaya meningkatkan kesejahteraan masyarakat KP, Kementerian Kelautan dan Perikanan dapat berbagi tugas dengan provinsi dengan mengutamakan beberapa peningkatan nilai kesejahteraan pada dimensi ekonomi ataupun dimensi sosial kelembagaan yang dinilai kurang tinggi. KKP dapat meminta provinsi yang memiliki indeks kesejahteraan kurang tinggi melakukan pengembangan ataupun inovasi program yang sebagaimana digambarkan dari indikator IKMKP ini dengan memberi/ menyalurkan DAK bagi provinsi tersebut sesuai tingkat indikator yang rendah tersebut. Sebagai contoh provinsi Kalimantan Tengah dirangsang untuk meningkat peningkatan ekonomi mikro serta mengembangkan wisata bahari disana. Hal ini karena kedua indikator tersebut memiliki bobot yang tinggi untuk meningkatkan kesejahteraan masyarakat.

\section{UCAPAN TERIMA KASIH}

Penulis mengucapkan terima kasih kepada pengelola serta Dewan Redaksi Jurnal Kebijakan Sosial Ekonomi Kelautan dan Perikanan Kementerian Kelautan dan Perikanan yang telah memberikan kesempatan untuk menulis artikel ini. Ucapan terima kasih juga kami sampaikan kepada Eselon 1 Lingkup Kementerian Kelautan dan Perikanan yang telah memberikan data-data yang dibutuhkan untuk analisis penghitumgan Indeks Kesejahteraan Masyarakat Kelautan dan Perikanan tahun 2017. 


\section{DAFTAR PUSTAKA}

Balai Besar Penelitian Sosial Ekonomi Kelautan dan Perikanan [PPSEKP]. 2015. Indeks Kesejahteraan Masyarakat Kelautan dan Perikanan: Konsep, Dimensi, dan Indikatornya. Working Paper No. 01/BBPSEKP/2015. Seri Analisis Kebijakan Pembangunan Kelautan dan Perikanan (Refocusing). Jakarta (ID): Badan Penelitian dan Pengembangan Kelautan dan Perikanan, Kementerian Kelautan dan Perikanan Republik Indonesia.

De Wel, B. 1995. "Indicadores Locales de Sus. tentabilidad: un instrumento para la Gestion Ambiental descentralizada ", Instituto de Ecología Politica: Santiago.

Dinas Kelautan dan Perikanan Nusa Tenggara Barat. 2017. Laporan Akuntabilitas Kinerja Tahun 2016. Palangkaraya

Dinas Kelautan dan Perikanan Provinsi Kalimantan Tengah.2017. Rencana Strategis Dinas Kelautan dan Perikanan Provinsi Kalimantan Tengah 2016-2021 Palangkaraya.

Wiyono dan Mustaruddin. 2016 Faktor-Faktor yang Mempengaruhi Kinerja Pembangunan Perikanan: Studi Kasus Pada Perikanan Tangkap Di Indramayu. Marine Fisheries Vol. 7(1) Hal: 109-115

Gasper, D. and Truong, T-D. 2010. Development Ethics through the Lenses of Caring, Gender and Human Security, In Capabilities, Power and Institutions: Towards a More Critical Development Ethics, eds. S. Esquith and F. Gifford, Pennsylvania State Univ. Press, University Park, PA, pp. 58-95.

Kementerian Kelautan dan Perikanan (KKP). 2015. Peraturan Menteri Kelautan dan Perikanan No. 45 tahun 2015 tentang Perubahan Atas Peraturan Menteri Kelautan dan Perikanan Republik Indonesia Nomor 25/Permen-Kp/2015 tentang Rencana Strategis Kementerian Kelautan dan Perikanan Tahun 2015-2019

Kementerian Koordinator Bidang Kesejahteraan Rakyat (Kemenkokesra). 2012. Indeks Kesejahteraan Rakyat (IKraR). Buku 1 dan 2. Jakarta (ID): Kementerian Koordinator Bidang Kesejahteraan Rakyat Republik Indonesia.

Musgrave, R.A. and M. Peggy. 1989. Public Finance in Theory and Practice 5 ed. Mcgraw-Hill. New York.

Norusis, M.J. (1993). SPSS for Windows : base system user's guide : release 5.0. Chicago (III.): SPSS.
Riyanto. 2003. Analisis Dampak Kebijakan Desentralisasi Fiskal terhadap Perekonomian Daerah dan Pemerataan Pembangunan Wilayah di Indonesia. Tesis. Sekolah Pascasarjana. Institut Pertanian Bogor. Bogor.

Saaty, T.L. 1993. Pengambilan Keputusan Bagi Para Pemimpin, P.T. Pustaka Binaman Pressindo, Jakarta. $\mathrm{F}$

Sen, A. 2000. A Decade of Human Development. Journal of Human Development, 1(1). Pp.17-23.

United Nations Development Programme (UNDP). 2004. Human Development Report 2004. New York: Oxford University Press

United Nations Development Programme (UNDP). 2004. Arab Human Development Report 2009 - challenges to Human Security in the Arab Countires. UNDP. New York. 